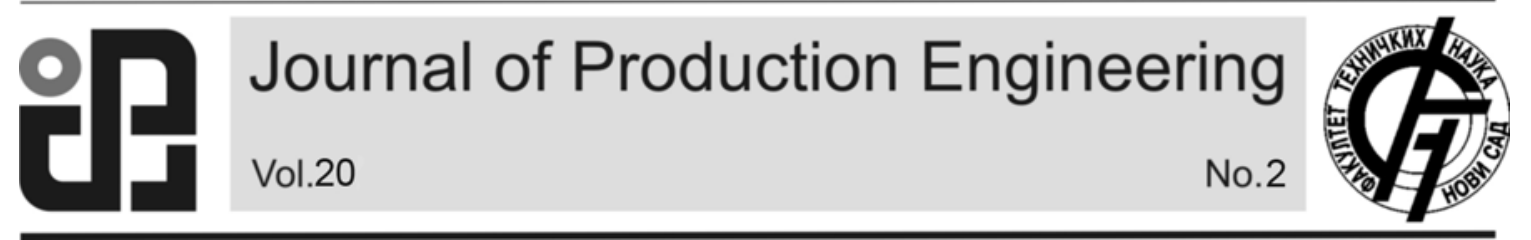

JPE (2017) Vol.20 (2)

Sahu, B., Nayak, N.C.

Preliminary Note

\title{
DEVELOPMENT OF A NEW METHODOLOGY FOR PERFORMANCE EVALUATION OF GREEN SUPPLY CHAIN MANAGEMENT IN ALUMINIUM INDUSTRY
}

\author{
Received: 14 September 2017 / Accepted: 08 November 2017
}

Abstract: This research considers seven critical practices from the production phase for implementing Green supply chain management (GSCM) practices. The study aims to describe the prominent factors responsible for GSCM practices and their priorities with productivity approach. The questionnaire has been developed to capture these prominent factors on a five point likert scale. A case study has been carried out. Data has been collected and analyzed using a balanced Analysis of Variance (ANOVA) method. It has been observed that recovery of the end-oflife products affect much for improving GSC practices.

Key words: Green Supply Chain, Inbound greening, Outbound greening, Reverse logistics, ANOVA, Optimization

Razvoj nove metodologije za vrednovanje performansi zelenog lanca upravljanja u aluminijumskoj industriji. Ovo istraživanje razmatra sedam kritičnih običaja iz proizvodne faze za sprovođenje upravljanja zelenim lancem snabdevanja (GSCM) u praksi. Studija ima za cilj da opiše istaknute faktore odgovorne za praksu GSCM-a $i$ njihove prioritete sa pristupom produktivnosti. Upitnik je razvijen tako da ove istaknute faktore uhvati na skali od 5 tačaka. Sprovedena je studija primera. Podaci su sakupljeni i analizirani pomoću balansirane metode analize varijanse (ANOVA). Primećeno je da oporavak proizvoda na kraju života značajno utiče na poboljšanje GSC-a prakse.

Ključne reči: Zeleni lanac snabdevanja, ulazno zeleno, izlazno zeleno, obrnuta logistika, ANOVA, optimizacija.

\section{INTRODUCTION}

Greening of the supply chain is one such innovative idea that is fast gaining attention in the industry. This may be primarily because many companies want to do something more than just taking typical measures such as implementing waste reduction strategies, installing pollution control technologies, replacing hazardous material inputs with environment-friendly alternatives, and so on.

Green supply chain management defined as "integration of environmental issues and burden into supply chain management in order to improve the environmental impact of the activities of supply chain i.e. product design, raw material sourcing and selection, manufacturing processes, delivery of the final product to the consumer as well as end-of-life of the product, while maintain the economic and operational performance" $[1,2]$.

GSCM is an important organizational philosophy, plays an important role in promoting efficiency and synergy between partners, facilitating environmental performance, minimal waste, while it improves the ecological efficiency of organizations and their partners. Before knowing the GSCM practices we should know about the various barriers to implementing GSCM in Indian manufacturing industry. The following four main barriers of GSCM implementation have been identified from the literature i.e. information gap, insufficient society pressure, poor legislation and capacity constraints [3].

In developing countries the increase of industrialization and globalization creates more opportunities for manufacturing industries but simultaneously increases environmental pressures. The aluminium industry shows a constant improvement and development of new technologies [4]. It fulfills an important role in our ordinary life. Three most properties characterize this metal: low density, high mechanical properties and good corrosion resistance. From an ecological point of view the metal is not consumed but simply reused during the product life time. This motivation justifies its nickname as green metal.

\subsection{Factors of GSCM}

Recently green supply chain management contains many logistics topics from in-bound logistics and supplier management, where logistics focuses on the movement of material and supplier management focuses on the relationships with the suppliers, in other words purchasing and its functions. This has grown to include the internal supply chain, production and outbound logistics [5] and even reverse logistics where the products after customer use are remanufactured and brought back to the incoming phase. For better understanding three factors are briefly described below; Reverse Logistics: is defined as the process of planning, implementing, and controlling the efficient, cost-effective flow of raw materials, in-process inventory, finished goods and related information from the point of consumption to the point of origin for the purpose of recapturing value or proper disposal [6]. The variables fall into this category are; using re- 
manufacturing and recovery of the end-of-life products. The main purpose behind reverse logistics is economical - cost minimizing and increasing profits.

Inbound Greening: It is fundamentally about green purchasing strategies adopted by the firms in response to ever-growing concerns of environmental sustainability all over the world [7]. This greening phase incudes choosing suppliers by environmental criteria, use of waste of other companies, urging suppliers(s) to take environmental actions.

Outbound Greening: In order to green this stage of the supply chain, the organization has to deal with green marketing, environment-friendly packaging, environment-friendly transportation, and environmentfriendly waste management. The critical practices belongs to this stages are recycling of waste material internal to the company and informing consumers on environmental friendly products.

The main objective of this research work is to find out the main critical factors and various hindering effect/barriers in GSCM practices in the production phase. This study identifies the effect of different variables on the quality of the product and correlates them with quality and the performance.

\section{REVIEW OF LITERATURE}

There are many factors which have a major effect on the performance of the industry/firm. It is necessary to study all the factors which have a direct impact on the performance of the enterprise and productivity [8]. Green supply chain plays an important role in improvement of the service performance and productivity of the firm. A brief observation on the literatures regarding green supply chain management (GSCM) over the last twenty to thirty years hasbeen discussed and the keydrivers for green initiatives to reduce the ecological impacts on industrial activity [9].

Performances in an industry i.e. economic, environmental, and social [10]; implementing the GSCM practices in industry has a positive impact on performances [11, 12]. Increasing environmental concern in ISO14001 certified manufacturing industries in a developed and developing countries has been the main business strategy for economic performances [13]. The initiatives for environmental enhancement, economic performance and competitiveness among the manufacturing industries like chemical, Electronics, automotive, furniture, computers, wind energy sector, aluminium, steel etc. [14, 15]; different sustainable and GSCM issues in supply networks in different economic sectors like utilities, transport, information and communication technology, retail, tourism, construction, food and farming, and public sector $[16,17]$ has been observed.

The various important hindering factors for implementing the GSCM practices in different manufacturing industries have been categories and the interaction between these factors in different phases of the industry has been summarized [18].

The researchers have used different methods i.e. Structural Equation Modeling (SEM) by [19], hypothesis test and multiple regression analysis by [20], fuzzy set theory and Decision Making Trial and Evaluation Laboratory (DMTEL) by [21], Interpretive Structural Modeling (ISM) by [22, 23], Analytical Hierarchy process by [24], sensitivity and reliability analysis by [25], ANOVA [26] to analyze the survey data and find the appropriate solution for the GSCM practices implementation in a manufacturing industry.

\section{THEORY AND METHODOLGY}

\subsection{Critical Practices of GSCM}

This research constitutes different critical practices for implementing GSCM practices. From the literature, seven critical practices have been selected which affect the GSCM practices in the industry. The various critical practices are described in Table. 1 .

In order to measure the critical GSCM practices and for a better understanding of seven GSCM practices are grouped into three factors i.e. reverse logistic greening, inbound greening and outbound greening; which has been discussed in introduction phase.

\begin{tabular}{|c|l|l|}
\hline Variables & \multicolumn{1}{|c|}{ Critical Practices } & \multicolumn{1}{|c|}{ References } \\
\hline VAR01 & Use of waste of other companies & Rao (2007) \\
\hline VAR02 & Recycling of material internal to the company & Mohanty\&Prakash (2014) \\
\hline VAR03 & Use of remanufacturing & Handfield et al. (2005) \\
\hline VAR04 & Choosing suppliers by environmental criteria & Yunang and Kielkiewiez (2001) \\
\hline VAR05 & Recovery of end-of-life product & Handfield et al. (2005) \\
\hline VAR06 & Urging supplier(s) to take environmental action & Rao (2007) \\
\hline VAR07 & Informing customers ofenvironmentally friendly products & Yunang and Kielkiewiez (2001) \\
\hline
\end{tabular}

Table 1.Critical practices selected from literatures

\subsection{Analysis of Variance}

Deco-positioning of total variability into its components is called ANOVA. It is a very important technique in the discipline of experimental statistics. Moreover, ANOVA can be very much used for analyzing the result of enquiries conducted in the field of industrial engineering. ANOVAs assess the importance of one or more factors by comparing the response variable means at the different factor levels. ANOVA uses F-tests to statistically test the equality of means. The F-statistic is simply a ratio of two variances. Variances are a measure of dispersion, or how far the data are scattered from the mean. Larger values represent greater dispersion. The procedure works by comparing the variance between group means versus the variance within groups as a way of determining whether the groups are all part of one larger population or separate populations with different characteristics. 


\section{DATA COLLECTION}

The following section describes the administration and the findings of this research. An empirical research has been conducted in an aluminium industry, which is a manufacturing sector.

\subsection{Sampling Frame}

There are many aluminium industries in Odisha, due to the accessibility in XYZ Ltd. The above industry was selected for this research work. Respondents were drawn from across three sections of the industry, i.e. Port room, Casting house and Research and Development.

\subsection{Sample Size}

In this research work the senior most professionals, technicians, junior engineers, senior engineers, Asst. manager in various departments have been considered as the respondents for the first hand data collection. A total of 110 questionnaires were distributed, out of which 40 were rejected because some of the questionnaires were unfilled, some were wrongly filled and half-filled. Finally 70 completely filled questionnaire was considered and based on this responses further study was conducted.

\subsection{Data Collection Method}

The data has been collected from questionnaires administered from 21 December 2016 to 10 February 2017. The questionnaire used in this research had seven statements (appendix) for design the profile of the target respondents in terms of environmental actions taken by their organization in the past 5 years, where the respondents had to agree on a five-point Likertscale, where $1=$ Very low, $2=$ Low, $3=$ Moderate, $4=$ High and $5=$ Very high

\section{DATA ANALYSIS, RESULTS AND DISCUSSIONS}

Pertinent data has been collected from various respondents using the questionnaire developed in chapter 3, with specific reference to an aluminium industry (XYZ Ltd.). A total number of 110 responses have been received in the process. Out of the total 70 number of useful data sets (attached in the appendix) were used in this research after outlier detections. Then the core/scaled data were normalized for further statistical analysis. The steps are described as follows:

\subsection{Measuring Implementation of Critical Practices}

With the objective of measuring the extent of implementation of the green supply chain initiatives, the ratings from survey responses were considered the three factors representing phases of the green supply chain. To assess the reliability of responses, Cronbach alpha coefficient was calculated. It is defined as a measure of internal consistency, i.e., how closely related a set of items are as a group. It is considered to be a measure of scale reliability. A commonly accepted rule for describing internal consistency using Cronbach alpha is as follows:

Internal consistency is considered excellent for $\alpha \geq$ 0.9 , good for $0.9 \leq \alpha<0.8$, acceptable for $0.8 \leq \alpha<$ 0.7 , questionable for $0.7 \leq \alpha<0.6$, poor for $0.6 \leq \alpha<$ 0.5 and unacceptable for $\alpha<0.5$.

The Cronbach alpha values for three factors have been calculated using SPSS software table 2.

\begin{tabular}{|l|l|}
\hline FACTORS & CRONBACH ALPHA \\
\hline Reverse logistics & 0.896188 \\
\hline Inbound greening & 0.990452 \\
\hline Outbound greenin & 0.779299 \\
\hline
\end{tabular}

Table 2.Reliability analysis for factors

Checking on the internal consistency, the values of Cronbach alpha are high indicating that the critical practices under each factor are strongly correlated and thus they measure the same attribute.

\subsection{ANOVA Test}

In this approach, the goodness-of-fit statistics model has been examined for the summarized ANOVA tables of three factors of GSCM practices and the output of the model are evaluated. The data has been analyzed using the Minitab-2017 software. The respondents' opinions has been analyzed for identifying the factors deeply and how it's affects the performance of the industry. The ANOVA was carried out for significance level of $\alpha=0.05$, i.e. for the confidence level of $95 \%$.

\subsubsection{Reverse Logistics}

From the ANOVA table, it is cleared that differences between the means are statistically significant; the value of $p=0.00(<0.05)$. In these results, the factor explains $100 \%$ of the variation in the response,so the data fitsbest in the model. $\mathrm{S}$ indicates that the standard deviation between the data points and the fitted values is approximately 0.001866 units. The last column of the table- 3 shows the percentage of contribution of critical practices out of total variation, indicating the degree of influence on the result. The percentage of contribution of the critical practices is $44 \%$ of the use of remanufacturing and $56 \%$ of Recovery of the end-of-life product towards reverse logistics.

\begin{tabular}{|c|c|c|c|c|c|c|c|}
\hline Sources & DF & SS & Adj. SS & Adj. MS & F & $p$ & \% Contribution \\
\hline VAR04 & 4 & 29.977 & 29.977 & 7.494 & 22.17 & 0.00 & 44 \\
\hline VAR05 & 4 & 38.534 & 38.534 & 9.633 & 40.71 & 0.00 & 56 \\
\hline Error & 16 & 0.000 & 0.00 & 0.00 & - & - & 0 \\
\hline Total & 24 & 68.52 & - & - & - & - & 100 \\
\hline
\end{tabular}

Note: $\mathrm{S}=0.001866 \quad \mathrm{R}-\mathrm{Sq}=100.00 \% \quad \mathrm{R}-\mathrm{Sq}(\operatorname{adj})=100.00 \%$

Table 3. ANOVA for Reverse logistic, using Adjusted SS 


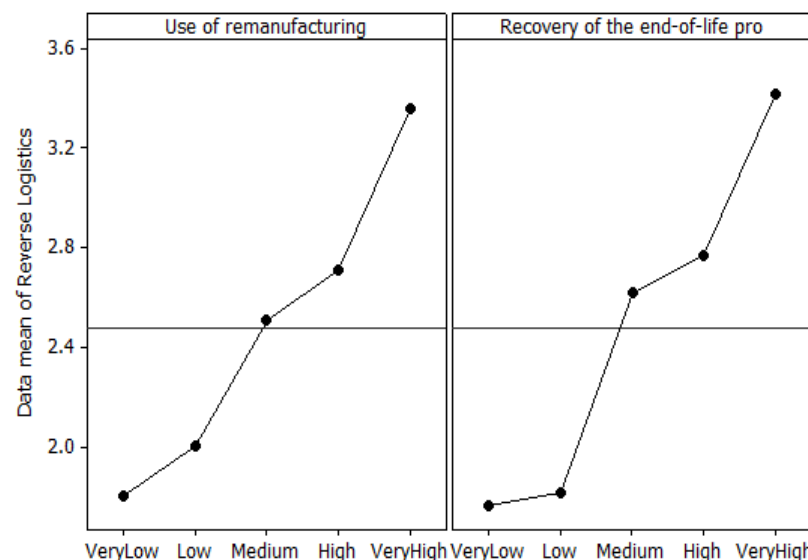

Fig.1. Main effect plot for Reverse logistics

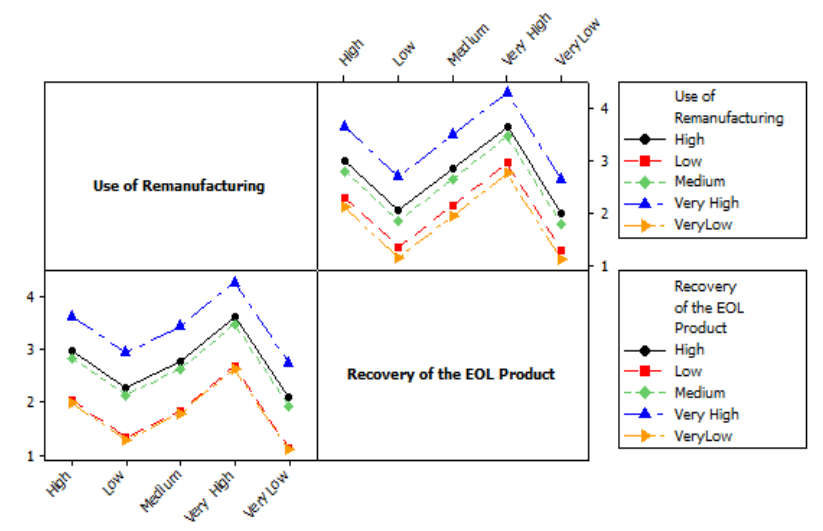

Fig.2. Interaction plot for Reverse logistics

In fig. 1 the mean values of the two critical practices have been compared. The graph indicates that both the critical practices of the reverse logistic, i.e. recovery of the end-of-life product and use of remanufacturing shows that the slope of the line is not steeper, so there is less magnitude of the main effect. In this interaction plot (fig. 2) the two variables show a greater degree of interaction at the high and medium level.

\subsubsection{Inbound Greening}

From the ANOVA the table. 4 , it is found that all the individual critical practices have significant effects on the inbound greening. All the interaction effects among the individual critical practices except one express significant effects towards the inbound greening at a significance level of 0.05 . In these results, the factor explains $98.27 \%$ of the variation in the response, so the data fits better in the model. The standard deviation between the data points and the fittedvalues is approximately 0.0813235 units. As compared to two critical practices of GSCM, i.e. choosing suppliers by environmental criteria and urging suppliers (s) to takeenvironmental actions, the third one i.e. use of waste of other companies gives less percentage $(26 \%)$ of contributiontoward inbound greening. Fig. 3 shows the main effect plot for inbound greening. From the main effect plot, the effect of individual critical practices on inbound greening has been defined subsequently. The slop lines indicatethat choosing a supplier by environmental criteria toslope line is steeper than the other two variables slop line, so the magnitude of the main effect is greater for choosing a supplier by environmental criteria. Fig. 4 shows the interaction effect between the critical practices.

\begin{tabular}{|c|c|c|c|c|c|c|c|}
\hline Sources & DF & SS & Adj.SS & Adj.MS & F & $p$ & \% Contribution \\
\hline VAR04 & 4 & 34.907 & 34.907 & 8.727 & 31.56 & 0.00 & 34 \\
\hline VAR01 & 4 & 26.787 & 26.787 & 6.696 & 12.61 & 0.00 & 26 \\
\hline VAR06 & 4 & 39.446 & 39.446 & 9.862 & 49.14 & 0.00 & 38 \\
\hline $\begin{array}{c}\text { VAR04* } \\
\text { VAR01 }\end{array}$ & 16 & 0.705 & 0.705 & 0.044 & 6.67 & 0.00 & 1 \\
\hline $\begin{array}{c}\text { VAR04* } \\
\text { VAR06 }\end{array}$ & 16 & 0.163 & 0.163 & 0.010 & 1.54 & 0.11 & 0 \\
\hline $\begin{array}{c}\text { VAR01* } \\
\text { VAR06 }\end{array}$ & 16 & 0.978 & 0.979 & 0.061 & 9.24 & 0.000 & 1 \\
\hline Error & 64 & 0.423 & 0.423 & 0.007 & - & - & 0 \\
\hline Total & 124 & 103.412 & - & - & - & - & 100 \\
\hline
\end{tabular}

Note: $\mathrm{S}=0.0813235 \quad \mathrm{R}-\mathrm{Sq}=99.59 \% \quad \mathrm{R}-\mathrm{Sq}(\mathrm{adj})=99.21 \%$

Table 4. ANOVA for Inbound Greening, using Adjusted SS

\subsubsection{Outbound Greening}

\begin{tabular}{|c|c|c|c|c|c|c|c|}
\hline Sources & DF & Seq SS & Adj.SS & Adj.MS & F & $p$ & \% contribution \\
\hline VAR02 & 4 & 9.596 & 9.596 & 2.399 & 18.51 & 0.00 & 34.009 \\
\hline VAR07 & 4 & 16.545 & 16.545 & 4.136 & 31.91 & 0.00 & 58.639 \\
\hline Error & 16 & 2.074 & 2.074 & 0.129 & - & - & 7.531 \\
\hline Total & 24 & 28.216 & - & - & - & - & 100 \\
\hline
\end{tabular}

Note: $\mathrm{S}=0.360053 \quad \mathrm{R}-\mathrm{Sq}=92.65 \% \quad \mathrm{R}-\mathrm{Sq}(\mathrm{adj})=88.97 \%$

Table 5. ANOVA for Outbound Greening, using Adjusted SS for Tests 


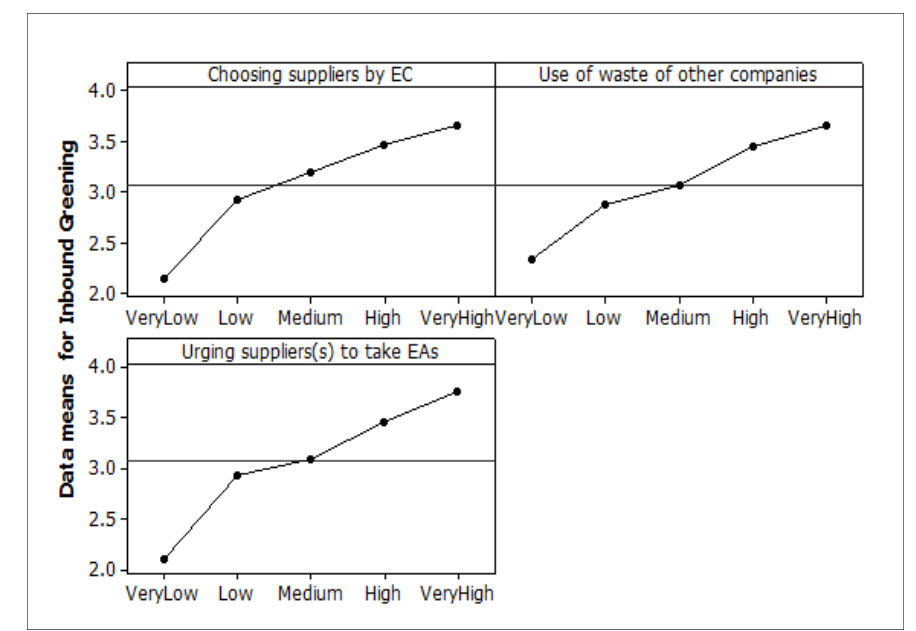

Fig. 3. Main effect plot for inbound greening

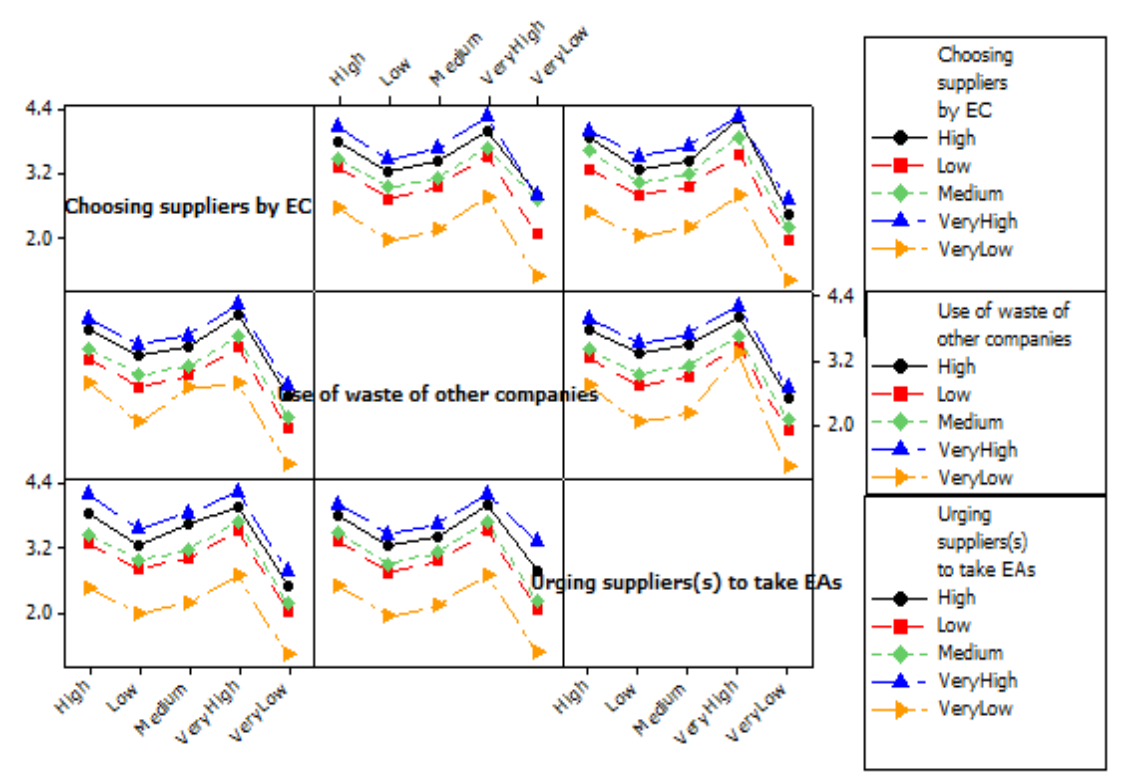

Fig. 4. Interaction plot for inbound greening

From the table it is cleared that differences between the means are statistically significant; the value of $p=0.00 \quad(<0.5)$. In these results, the factor explains $92.65 \%$ of the variation in the response,so the data fits better in the model. The percentage of contribution of the critical practices is $34 \%$ of recycling of waste materials internal to the company and $58.64 \%$ of informing consumers on environmentally friendly products towards outbound greening.

The graph (fig. 5) below indicates that both the critical practicesshow that the slope of the line is steeper, so there is the greater magnitude of the main effect.In the above interaction plot (fig. 6) the two variables show a greater degree of interaction.

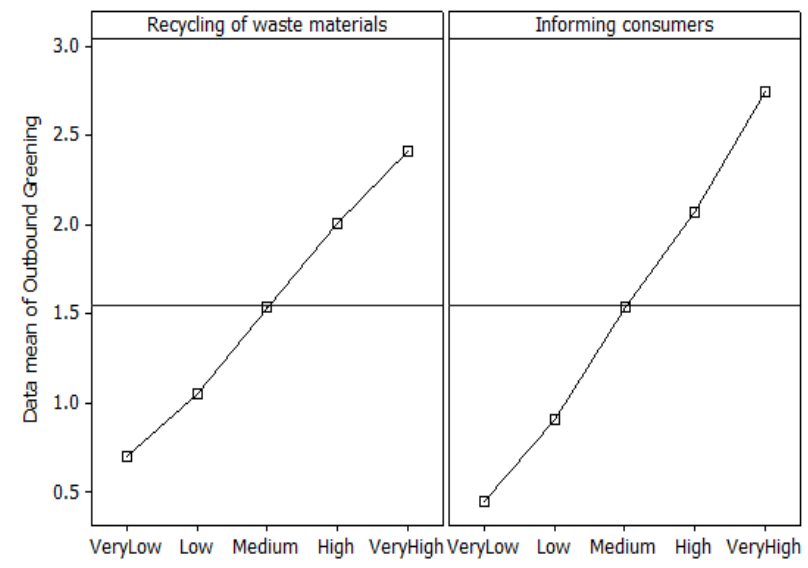

Fig. 5. Main effect plot for outbound greening 


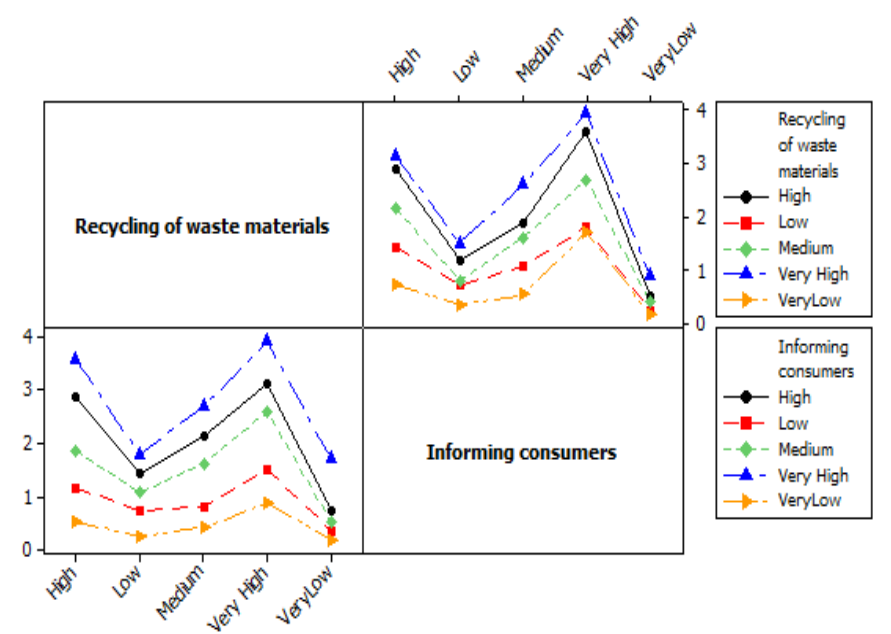

Fig. 6. Interaction plot for Outbound greening

\section{CONCLUSIONS}

Greening has been understood to be linked with a strong colour often associated with life, fertility and health. Being green has become an important marketing tool for economic performance. In a developing country like India, there is a rapid growth in industries which gives more opportunities for manufacturing sector but also increase the environmental burden.From the reliability analysis, the values of Cronbach alpha are found to be high. Thus, it indicates that the critical practices under each factor are strongly correlated and the internal consistency is good for all the three GSCM factors. From the ANOVA table of three factors, using adjusted sum of squares for tests shows that the probability values are less than the level of significance i.e. $\alpha=0.05$, which means the model is statistically significant. R-Sq is the percentage of variation in the response that is explained by the model. The higher the R-sq value, the better the model fits the data. In this analysis, R-sq value for all the six factors is in between $90 \%$ to $100 \%$.

- As far as the reverse logistic is concerned both the input variables significantly affects the output. However, recovery of the end-of-life products affects much for improving reverse logistics.

- As far as the inbound greening is concerned three input variables significantly affects the output. However, urging supplier(s) to take environmental actions affect more for improving inbound greening.

- Insofar as the out bound greening is concerned both the input variables significantly affects the output. However, informing consumer on environmental friendly products affect much for improving the outbound greening.

For the complete implementation of GSCM practices in the industry, users may focus their attention to the above mentioned practices for more productivity, less/zero waste, with improved product quality.

\section{SCOPE FOR FUTURE RESEARCH}

This research has certain limitations. The research has covered only three important sections in a leadingaluminium industry. The critical practices for GSCM implementation has been captured only in production phase initiatives using the questionnaire survey. Thus, further research work may be carried out in the other sections of the above industry and the data may be collected from other more industries (like mining, steel, electronics, automotive etc.) as well for validating the results as has been obtained in this research. In the case of large data sample, Structural Equation Modeling (SEM) method may be used/constructed in this research work.

\section{REFERENCES}

[1] Beamon, B. M.: Designing the green supply chain, Logistics Information Management, Vol. 12, No. 4, p.p. 332-342, 1999.

[2] Mutingi, M.: Developing green supply chain management strategies: A taxonomic approach, Journal of Industrial Engineering and Management JIEM, 6(2), p.p. 525-546, 2013.

[3] Jayant, A., Azhar, M.: Analysis of the barriers for implementing green supply chain management (GSCM) Practices: An Interpretive Structural Modeling (ISM) Approach, Procedia Engineering, vol97, p.p. 2157-2166, 2014.

[4] Ferretti, I., Zanoni, S., Zavanella, L., Diana, A.: "Greening the aluminium supply chain", Int. J. Production Economics, 108, p.p. 236-245, 2007.

[5] Srivastava, S. K.: Green supply-chain management: a state-of-the-art literature review, International Journal of Management Reviews, 9 (1), p.p. 53-80, 2007.

[6] Olariu, I.: Conceptual issues regarding reverse logistics, Studies and Scientific Researches Economics Edition, vol.18, p.p. 326-331, 2013.

[7] Chen, Y.: The driver of green innovation and green image-green core competence, Journal of business ethics, 81.3, p.p. 531-543, 2008.

[8] Mishra, D., Gunasekaran, A., Papadopoulos, T., Hazen. B.: Green supply chain performance measures: A review and bibliometric analysis, Sustainable production and consumption, vol.10, p.p. 85-99, 2017.

[9] Dubey, S. A., Gawande, Dr. R. R.:Green supply chain management - A literature review, International Journal of Computer Applications, p.p.0975-8887, 2011. 
[10] Geng, R., Mansouri, S. A., Aktas, E.: The relationship between green supply chain management and performance: A meta-analysis of empirical evidences in Asian emerging economics, Int. J. Production Economics, 183, p.p. 245-258, 2017.

[11] Vanalle, R. M., Ganga,G. M. D., Filho. M. G.: Green supply chain management: An investigation of pressures, practices, and performance within the Brazilian automotive supply chain, Journal of Cleaner Production, 151, p.p. 250-259, 2017.

[12] Sulaiman, Z., Tat, H. H., Zainon, S. N., Muhamad, L.:Green supply chain management practices and sustainability performance, Journal of Management and Sustainability, vol. 5, No.1, p.p. 149-157, 2015.

[13] Hazikhani, M., Wahiza, N., Bin, K.: Considering on Green Supply Chain Management Drivers, as strategic organizational development approach, Malaysian perspective, Australian Journal of Basic and Applied Sciences, 6(8), p.p. 246-265, 2012.

[14] Poulsen, T., Lema, T.: Is the supply chain ready for the green transformation? The case of offshore wind logistics, Renewable and Sustainable Energy Reviews, vol.73, p.p. 758-771, 2017.

[15] Azevedo, S. G., Carvalho, H., Machado V. C.:The influence of green practices on supply chain performance: A case study approach, Transportation Research Part, vol. 47, p.p. 850871, 2011.

[16] Das, P. K., Nayak, N. C.:Assessment Modeling and Optimization of efficiency in Rice Supply Chain from a Farmers' Perspective: Study of Rice Supply Chain in Indian, International Journal of Operation And Logistic Management, Vol. 5, No.3, p.p. 164189, 2016.

[17] Young, A., Kielkiewicz-Young, A.: Sustainable supply network management, Corporate environmental strategy, 8.3, p.p. 260-268, 2001.

[18] Mehar, A.N., Agi, Rohit, N.: Understanding influential factors on implementing Green Supply Chain Management practices: An Interpretive Structural Modeling analysis, Journal of Environmental Management, vol. 188, p.p. 351$365,2017$.
[19] Mohanty, R.P., Prakash, A.: Green supply chain practices in India: a confirmatory empirical study, Production \& Manufacturing Research: An open Access Journal, Vol. 2, No. 1, p.p. 438-456, 2014.

[20] Chang,B., Kenzhekhanuly, Y., Park, B.:A Study on Determinates of Green Supply Chain Management Practices, International Journal of Control and Automation, vol.6, No.3, p.p. 199-208, 2013.

[21] Li Ai, Q., Found, P.: Lean and Green Supply Chain for the Product-Service System (PSS): The Literature Review and A Conceptual Framework, Procedia CIRP 47, p.p. 162-167, 2016.

[22] Das P. K.,Nayak N. C.: Modeling supply chain of rice, uncertainty factors \& strategic supply management, Int. Jrl. of Logistics Systems \& Mgt, vol. 27, no. 3, pp. 343-362, 2017.

[23] Dubey, R., Angappa, G., Thanos, P.:Green supply chain management enablers: Mixed method research", Sustainable Production and Consumption, vol.4, p.p. 72-88, 2015.

[24] Kamolkittiwong, A., Phruksaphanrat, B.: An Analysis of Drivers Affecting Green Supply Chain Management Implementation in Electronics Industry in Thailand, Journal of Economics, Business and Management, vol. 3, No. 9, p.p. 864869, September 2015.

[25] Sharma, V. K., Chandna, P., Bharadwaj, A.: Green supply chain management related performance indicators in agro industry: A review, Journal of Cleaner Production, 141, p.p. 1194-1208, 2017.

[26] Rao, P.: Greening of the supply chain: An empirical study for SMES in the Philippine Context, Journal of Asia Business Studies, 1.2, p.p. 55-66, 2007.

Authors: Bandita Sahu, M.Tech Scholar in Mechanical Engineering Department, Indira Gandhi Institute of Technology (An Autonomous Institute of Govt. of Odisha), Sarang, India-759146.

Dr. Narayan C. Nayak, Phd, Reader in Mechanical Engineering Department, Indira Gandhi Institute of Technology (An Autonomous Institute of Govt. of Odisha), Sarang, India-759146 (Corresponding Author).

E-mail: nayak.iem@gmail.com

\section{Questionnaire}

\section{$\underline{\text { APPENDIX }}$}

On the basis of past 5years, the respondents are requested to rate on a scale of $\mathbf{1}$ to 5 , where $\mathbf{1}=$ Very low, $2=$ Low, 3 = Moderate, 4 = High, 5 = Very high.

Respondents are also requested to add any variables, if any, relevant to Green Supply Chain Management.

Name:

Designation:

\begin{tabular}{|c|c|c|c|c|c|c|}
\hline Variables & Critical Practices (description of the variables) & 1 & 2 & 3 & 4 & 5 \\
\hline VAR01 & Use of waste of other companies & & & & & \\
\hline VAR02 & Recycling of material internal to the company & & & & & \\
\hline VAR03 & Use of remanufacturing & & & & & \\
\hline VAR04 & Choosing suppliers by environmental criteria & & & & & \\
\hline VAR05 & Recovery of end-of-life product & & & & & \\
\hline VAR06 & Urging supplier(s) to take environmental action & & & & & \\
\hline VAR07 & Informing customers ofenvironmentally friendly products & & & & & \\
\hline
\end{tabular}

